\title{
ANALISIS TINGKAT KEBISINGAN \\ PADA KAWASAN SEKOLAH DASAR DI MAKASSAR
}

\author{
ANAL YSIS OF NOISE LEVEL \\ ON ELEMENTARY SCHOOL IN MAKASSAR
}

\author{
Nurul Rizki Nurasrin $^{* 1}$, Muralia Hustim $^{1)}$, dan Rita Irmawati ${ }^{1)}$ \\ ${ }^{1)}$ Departemen Teknik Lingkungan, Fakultas Teknik, Universitas Hasanuddin, \\ Jl. Poros Malino Gowa KM. 6 Bontomarannu, Gowa, Sulawesi Selatan, 92172 \\ ${ }^{*}$ E-mail: nurul.rizki15@yahoo.com
}

\begin{abstract}
Abstrak
Penelitian dilaksanakan di SD Bawakaraeng Makassar yang berlokasi dekat dengan salah satu jalan arteri di kota Makassar. Sekolah dasar ini mempunyai jarak dari gedung ke jalan paling dekat yaitu 11,2 meter dan berlokasi dekat dengan traffic light, sehingga terjadi perlambatan kendaraan di sekitar Sekolah Dasar tersebut yang menyebabkan adanya kebisingan. Penelitian ini bertujuan untuk menganalisis tingkat kebisingan, memetakan sebaran tingkat kebisingan, dan mengetahui persepsi masyarakat (siswa, guru, staf, orang tua siswa) akibat tingkat kebisingan di SD Bawakaraeng Makassar. Penentuan titik pengukuran dilakukan pada aplikasi google earth, kemudian pada saat di lapangan titik koordinatnya disesuaikan menggunakan aplikasi GPS Tracker Lite pada handphone android. Pengukuran tingkat kebisingan dilakukan di 42 titik pada area SD Bawakaraeng dengan menggunakan alat Sound Level Meter TM-103 yang dilakukan selama 10 menit pada setiap titik dan data yang diperoleh adalah data tingkat kebisingan. Pemetaan sebaran tingkat kebisingan menggunakan aplikasi surfer 7.0 dan untuk mengetahui persepsi akibat tingkat kebisingan di SD Bawakaraeng dilakukan dengan membagikan kuesioner sebanyak 250 responden. Berdasarkan hasil penelitian bahwa nilai tingkat kebisingan rata-rata adalah 76,44 dBA. Ini menunjukkan bahwa tingkat kebisingan di sekitar SD Bawakaraeng melebihi baku mutu yaitu 55 dBA. Peta sebaran tingkat kebisingan di SD Bawakaraeng dominan berwarna kuning yang artinya tingkat kebisingan rata-rata di antara 70-80 dBA. Berdasarkan kuesioner yang telah dibagikan, seluruh responden merasa ribut dengan kebisingan di SD Bawakaraeng dan sebagai upaya pengendalian kebisingan dominan responden memilih pembatasan kecepatan kendaraan sebagai solusinya.
\end{abstract}

Kata kunci: Kebisingan, Pengendalian Kebisingan, Sebaran Tingkat Kebisingan, Survey Persepsi.

\begin{abstract}
The research was conducted in Bawakaraeng Elementary School (SD) Makassar, located close to one of the arterial roads in Makassar city. The shortest distance between the school's buildings and the road is 11.2 meters and it is located near traffic lights, causing noise around the school area due to vehicles slowing down. This study aimed to analyse the level of noise, map the distribution of the noise level, and determine the perception of public (students, teachers, staff, parents) on the noise level at SD Bawakaraeng Makassar. Points of measurement were determined using Google Earth, and the data were then transferred to the GPS Tracker Lite application to be used on site using an android mobile phone. Noise level measurement was performed at 42 points at SD Bawakaraeng area using a Sound Level Meter TM-103, conducted for 10 minutes at each point, to obtaine noise level data. Mapping of the noise level distribution was done using the application Surfer 7.0. To find out the perception on to the noise level at SD Bawakaraeng, questionnaires were distributed to 250 respondents. Based on the research, the average noise level was 76.44 dBA. It shows that the noise level around SD Bawakaraeng exceeded the quality standard of $55 \mathrm{dBA}$. Mapping of the noise level at SD Bawakaraeng showed yellow as the dominant color which means that the level of noise averaged between 70-80 dBA. Based on the questionnaires distributed, all respondents felt disturbed by noise at SD
\end{abstract}


Bawakaraeng and as an effort to control the noise at SD Bawakaraeng, most of the respondents preferred to restrict the speed of vehicle as a solution.

Keywords: Distribution, Elementary School, Measurment, Noise Level, SD.Bawakaraeng.

\section{PENDAHULUAN}

Kota Makassar merupakan salah satu kota metropolitan di Indonesia yang mengalami penurunan kualitas lingkungan yang disebabkan oleh permasalahan transportasi kota. Hal ini dapat dilihat dengan terjadinya kemacetan pada setiap jam sibuk, volume kendaraan bermotor terus meningkat tanpa terkendali. Sementara banyak jalan raya telah mencapai tingkat jenuh yang tinggi di mana jumlah kendaraan yang melalui jalan tersebut nyaris melebihi kapasitasnya. Padatnya aktikvitas penduduk kota Makassar pada saat ini menyebabkan meningkatnya jumlah kendaraan bermotor di jalan raya sehingga aktivitas lalu lintas juga semakin padat.

Tingkat pertumbuhan kendaraan pada tahun 2012 untuk roda dua di kota Makassar $11 \%$, mobil penumpang $1 \%$ dan angkutan umum 2,7\% (Satlantas Polrestabes Makassar, 2013), sedangkan jalan hanya $1-3 \%$ per tahun (Muralia Hustim, 2012). Hal ini menunjukkan terjadinya ketidakseimbangan antara pertumbuhan kendaraan dengan pertumbuhan prasarana, yang memicu terjadinya kemacetan yang berakibat pada kebisingan.

Berdasarkan penelitian terdahulu kebisingan lalu lintas jalan di kota Makassar di atas 70 dB (Muralia Hustim, 2012). Ini menunjukkan bahwa tingkat kebisingan di jalan sudah melebihi baku mutu, dimana menurut Keputusan Menteri Lingkungan Hidup No. 48 tahun 1996 maksimum kebisingan adalah $70 \mathrm{~dB}$ untuk semua tata guna lahan. Kondisi ini dapat mengganggu kenyamanan yang berada disekitar jalan. Salah satu fungsi tata guna lahan yang yang harus diperhatikan adalah sekolah yang menurut Keputusan Menteri Negara Lingkungan Hidup No. 48
Tahun 1996 tentang baku mutu kebisingan, batas paparan tingkat kebisingan untuk kawasan sekolah yang diperbolehkan tidak lebih dari $55 \mathrm{~dB}$.

Akibat dari tingginya pertumbuhan ekonomi dan transportasi saat ini di Indonesia, beberapa sekolah di perkotaan yang dulunya jauh dari kebisingan, kini harus berada dalam lingkungan yang tidak kondusif lagi sebagaimana layaknya lingkungan pendidikan. Pencemaran atau kebisingan tidak terhindarkan lagi sehingga banyak sekolah- sekolah berada dalam lingkungan kesibukan lalu lintas, yang secara langsung atau tidak langsung mempengaruhi proses belajar mengajar. Kebisingan yang terjadi juga dapat menimbulkan gangguan fisiologis dan psikologis bagi siswa, seperti komunikasi yang kurang jelas dan kurang konsentrasi pada saat menerima pelajaran.

Di kota Makassar terdapat beberapa sekolah khususnya sekolah dasar yang berlokasi di dekat jalan utama kota Makassar, seperti SD Panaikang, SD Ikip, SD Maccini, SD Bawakaraeng, SD Sudirman, SD Nasional, dan lain-lain. Akan tetapi SD Bawakaraeng merupakan sekolah kompleks, yang di dalamnya terdapat 4 sekolah dasar, dan memiliki jarak gedung paling dekat dengan jalan utama yaitu 11,2 meter, sehingga sekolah ini ramai dengan kendaraan bermotor dari pengantar/penjemput siswa dan kendaraan bermotor yang lewat di jalan utama yaitu Jalan Gunung Bawakaraeng, yang dapat menyebabkan tingginya tingkat kebisingan di kawasan sekolah dasar tersebut.

Mengingat pentingnya kenyamanan kawasan sekolah, khususnya sekolah dasar yang terhindar dari kebisingan kendaraan di jalan raya, dan kebisingan lingkungan sekitar yang 
akan berpengaruh terhadap proses belajar mengajar, komunikasi yang kurang jelas dan kurang konsentrasi pada saat menerima pelajaran sehingga perlu dilakukan penelitian dengan tujuan untuk menganalisis tingkat kebisingan di SD Bawakaraeng Makassar, memetakan sebaran tingkat kebisingan di SD Bawakaraeng Makassar, dan mengetahui persepsi masyarakat (siswa, guru, pegawai, dan orang tua siswa) akibat tingkat kebisingan di SD Bawakaraeng Makassar.

\section{METODA}

Tahapan penelitian meliputi studi pendahuluan; persiapan lokasi, alat, dan bahan yang digunakan; pengambilan data; dan analisis data. Tahapan penelitian yang akan dilakukan diuraikan pada kerangka penelitian (Gambar 1).
Penelitian ini dilakukan di SD.Bawakaraeng Makassar selama dua hari yaitu pada tanggal 29 - 30 September 2014. Penelitian dimulai dengan pemasangan patok/ penandaan titik pengukuran tingkat kebisingan sesuai titik yang telah ditentukan. Penentuan titik dilakukan secara grid mengikuti luas area sekolah tersebut. Kemudian dilakukan pengukuran tingkat kebisingan secara langsung menggunakan Sound Level Meter TM-103 yang dilakukan selama 10 menit (600 detik) pada setiap titik yang sudah di tentukan dan dilakukan penyebaran kuesioner ke 250 responden untuk mengetahui persepsi masyarakat (siswa kelas $6 \mathrm{SD}$, guru, staf, dan orang tua siswa/ pengantar penjemput siswa) terhadap kebisingan pada kawasan SD.Bawakaraeng Makassar serta bagaimana upaya pengendaliannya.

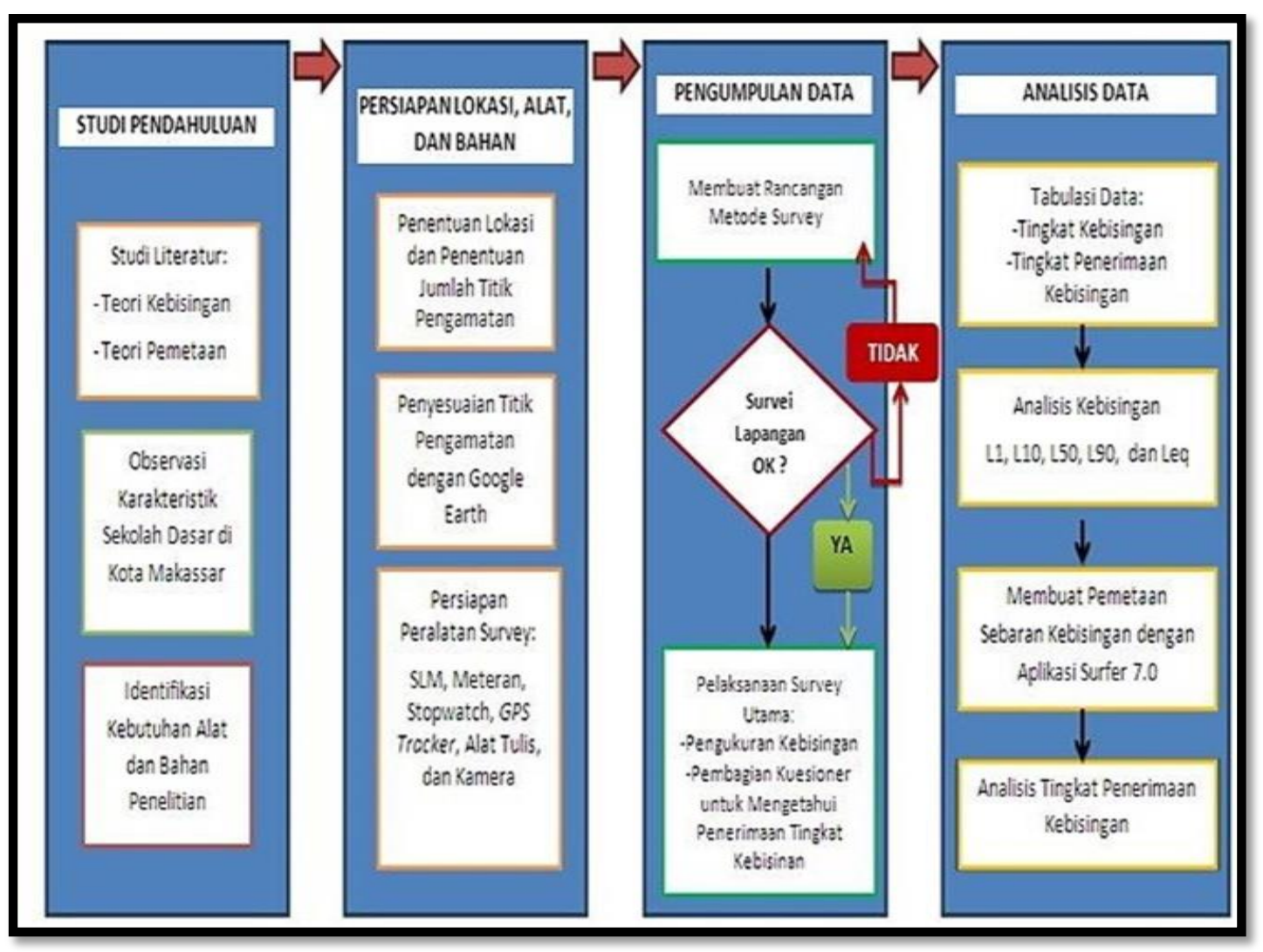

Gambar 1. Skema Kerangka Penelitian 
Pengukuran tingkat kebisingan dilakukan di 42 titik pada kawasan SD.Bawakaraeng Makassar, yaitu 39 titik berada di dalam area sekolah (lapangan sekolah), 2 titik berada di halaman/ pekarangan/ tempat parkir sekolah (masing-masing dekat dengan pintu gerbang sekolah), dan 1 titik berada di luar area sekolah/ dekat dengan jalan raya (Gambar 2).

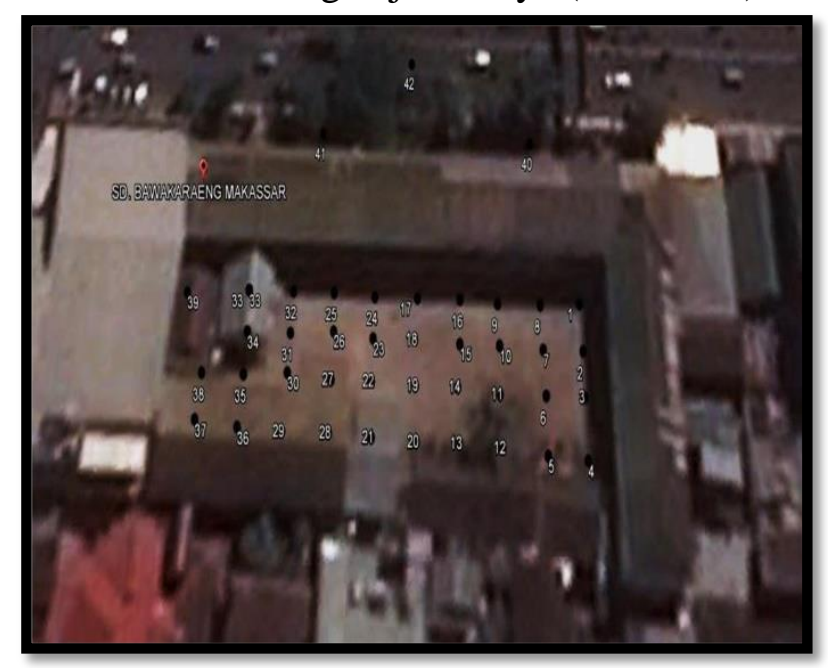

Gambar 2. Lokasi Titik Pengukuran

\section{HASIL DAN PEMBAHASAN}

Berdasarkan pengolahan data titik 1 (Tabel 1) dapat dilihat hubungan antara tingkat bising $(\mathrm{dB})$ dan frekuensi $(\%)$ berdasarkan klasifikasinya dalam bentuk histogram (Gambar 3), yang selanjutnya dapat dihitung luas area histogramnya untuk mengetahui nilai L90, L50, L10, dan L1 yang dapat digunakan untuk menghitung nilai Leq setiap titik.

Persentase yang mewakili tingkat kebisingan minoritas adalah kebisingan yang muncul $10 \%$ dari keseluruhan data (L10) dan tingkat kebisingan mayoritas yang muncul adalah $90 \%$ dari data pengukuran (L90). Persentase tengah (L50) umumnya identik dengan kebisingan rata-rata selama periode pengukuran. L90 disebut kebisingan buangan atau sisa dan L10 adalah tingkat kebisingan yang umumnya menimbulkan gangguan.

Tabel 1. Pengolahan Data Titik 1

\begin{tabular}{|c|c|c|c|c|}
\hline No & Interval Bising & $\begin{array}{c}\text { Nillai } \\
\text { Tengah }\end{array}$ & Frekuensi & $\begin{array}{l}\text { Frekuensi } \\
(\%)\end{array}$ \\
\hline 1 & $67.01 \cdot 69.00$ & 68.01 & 7 & 1.17 \\
\hline 2 & $69.01 \cdot 71.00$ & 70.01 & 25 & 4.17 \\
\hline 3 & $71.01 \cdot 73.00$ & 72.01 & 67 & 11.17 \\
\hline 4 & $73.01 \cdot 75.00$ & 74.01 & 122 & 20.33 \\
\hline 5 & $75.01 \cdot 77.00$ & 76.01 & 121 & 20.17 \\
\hline 6 & $77.01 \cdot 79.00$ & 78.01 & 83 & 13.83 \\
\hline 7 & $79.01 \cdot 81.00$ & 80.01 & 64 & 10.67 \\
\hline 8 & $81.01 \cdot 83.00$ & 82.01 & 48 & 8.00 \\
\hline 9 & $83.01 \cdot 85.00$ & 84.01 & 32 & 5.33 \\
\hline 10 & $85.01 \cdot 87.00$ & 86.01 & 16 & 2.67 \\
\hline 11 & $87.01 \cdot 89.00$ & 88.01 & 11 & 1.83 \\
\hline 12 & $89.01 \cdot 91.00$ & 90.01 & 4 & 0.67 \\
\hline
\end{tabular}

Khusus untuk di jalan raya, L90 akan menunjukkan tingkat kebisingan latar belakang dan L10 menunjukkan perkiraan tingkat kebisingan maksimum sehingga L10 adalah sistem pengukuran angka penunjuk yang harus benar-benar diperhatikan. L10 dan Leq dijadikan acuan untuk dibandingkan dengan bakuan yang berlaku, sementara L90 dapat diabaikan karena umunya tidak selisih jauh dengan bakuan. Gambar hubungan antara tingkat bising (dB) dan frekuensi (\%) untuk semua titik pengukuran dapat dilihat pada lampiran 3.

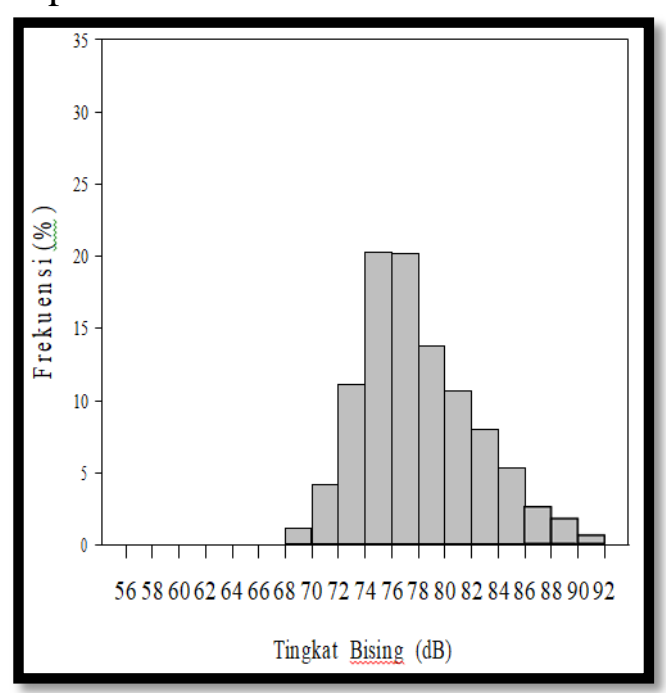

Gambar 3. Tingkat Bising (dB) terhadaFrekuensi(\%) pada Titik 1 
Berdasarkan histogram hubungan tingkat bising (dB) terhadap frekuensi (\%) (gambar 3), luas area dalam histogramnya yaitu.

$=2(1.17+4.17+11.17+20.33+20.17$

$+13.83+10.67+8.00+5.33+2.67+$

$1.83+0.67)=200$

Untuk menghitung L90, dihitung dengan cara: $2(1.17+4.17+)+11.17 \mathrm{x}=0.1(200)$

$$
\mathrm{x}=0.83
$$

Sehingga,

$\mathrm{L} 90=71 \mathrm{dBA}+0.83 \mathrm{dBA}=71.83 \mathrm{dBA}$

L50 dihitung dengan cara:

$2(1.17+4.17+11.17+20.33)+$

$20.17 \mathrm{x}$

Sehingga,

$$
\mathrm{y} \quad=1.31
$$

$\mathrm{L} 50=75 \mathrm{dBA}+1.31 \mathrm{dBA}=76.31 \mathrm{dBA}$

L10 dihitung dengan cara:

$2(1.17+4.17+11.17+20.33+$

$20.17+13.83+10.67+8.0)+$

$5.33 \mathrm{x}=0.9(200)$

Sehingga,

$\mathrm{L} 10=83 \mathrm{dBA}+0.19 \mathrm{dBA}=83.19 \mathrm{dBA}$

Dengan demikian, untuk memperoleh nilai Leq, perlu melakukan perhitungan L1 terlebih dahulu. L1 dihitung dengan cara:

$2(1.17+4.17+11.17+20.33+$

$20.17+13.83+10.67+8.00+5.33+$

$2.67)+1.83 q=0.99(200) q \quad=1.64$

Sehingga,

$\mathrm{L} 1=87 \mathrm{dBA}+1.64 \mathrm{dBA}=88.64 \mathrm{dBA}$

Jadi, Leq untuk titik 1 yaitu:

Leq $=76.31+0.43(88.64-76.31)=81.6 \mathrm{dBA}$

Dengan menggunakan luasan histogram untuk setiap titik pengukuran, maka di peroleh nilai
L90, L50, L10, L1, dan Leq untuk setiap titik pengukuran tingkat kebisingan pada kawasan SD Bawakaraeng (Tabel 2). Nilai tingkat kebisingan yang diperoleh dari pengukuran tingkat kebisingan pada kawasan SD Bawakaraeng Makassar untuk semua titik (42 titik) melebihi 55 dBA. Sehingga dapat dinyatakan bahwa tingkat kebisingan pada kawasan SD Bawakaraeng Makassar melebihi baku mutu kebisingan berdasarkan standar baku mutu kebisingan untuk kawasan sekolah sesuai Keputusan Menteri Negara Lingkungan Hidup Nomor 48 Tahun 1996 tentang baku mutu lingkungan yaitu $55 \mathrm{dBA}$.

Pemetaan tingkat kebisingan dilakukan dengan menentukan titik survei pada aplikasi Google Earth. Menentukan titik di aplikasi Google Earth, dapat membantu mengetahui letak koordinat titik survei yang telah diubah dari derajat ke bentuk satuan desimal.

Tabel 2. Tingkat Kebisingan untuk setiap titik

\begin{tabular}{|c|c|c|c|c|c|}
\hline \multirow{2}{*}{ TITIK } & \multicolumn{5}{|c|}{ Tingkat Kebisingan (dBA) } \\
\cline { 2 - 6 } & L90 & L50 & L10 & L1 & Leq \\
\hline 1 & 71.84 & 76.31 & 83.19 & 88.64 & 81.61 \\
\hline 2 & 71.46 & 75.49 & 81.11 & 85.18 & 79.66 \\
\hline 3 & 68.93 & 72.67 & 78.09 & 83.19 & 77.19 \\
\hline 4 & 65.46 & 68.41 & 73 & 78.71 & 72.84 \\
\hline 5 & 67.78 & 71.24 & 75.73 & 81.19 & 75.52 \\
\hline 6 & 67.45 & 70.87 & 75.04 & 79.09 & 74.4 \\
\hline 7 & 64.04 & 66.78 & 70.4 & 75 & 70.31 \\
\hline 8 & 65.89 & 69.37 & 74.07 & 77.92 & 73.05 \\
\hline 9 & 69.43 & 73.64 & 79.63 & 84.09 & 78.13 \\
\hline 10 & 70.3 & 74.14 & 79 & 84.84 & 78.74 \\
\hline 11 & 68.24 & 72.26 & 79 & 87 & 78.6 \\
\hline 12 & 66.77 & 70.82 & 76.36 & 80.33 & 74.91 \\
\hline 13 & 65.91 & 68.98 & 73.43 & 79.18 & 73.37 \\
\hline 14 & 69.36 & 72.6 & 78.06 & 82.8 & 76.99 \\
\hline 15 & 62.96 & 67.1 & 72.69 & 77 & 71.36 \\
\hline 16 & 58.36 & 61.9 & 66.8 & 73 & 66.67 \\
\hline 17 & 59.23 & 64.23 & 73.67 & 85.67 & 73.45 \\
\hline 18 & 59.99 & 61.34 & 67.29 & 72.2 & 66.01 \\
\hline 19 & 67.25 & 72.17 & 78.37 & 85.4 & 77.86 \\
\hline 20 & 68.42 & 71.92 & 76.21 & 81 & 75.82 \\
\hline 21 & 69.71 & 73.5 & 78.88 & 83.5 & 77.8 \\
\hline 22 & 69.56 & 73.27 & 78.36 & 84.71 & 78.19 \\
\hline 23 & 58.45 & 62.53 & 67.76 & 74.33 & 67.6 \\
\hline
\end{tabular}




\begin{tabular}{|c|c|c|c|c|c|}
\hline \multirow{2}{*}{ TITIK } & \multicolumn{5}{|c|}{ Tingkat Kebisingan (dBA) } \\
\cline { 2 - 6 } & L90 & L50 & L10 & L1 & Leq \\
\hline 24 & 62.06 & 66.33 & 73.17 & 80.2 & 72.29 \\
\hline 25 & 67.19 & 73.1 & 80.23 & 87.86 & 79.45 \\
\hline 26 & 71.09 & 77.94 & 82.67 & 87.86 & 82.21 \\
\hline 27 & 68.9 & 71.88 & 76.48 & 81.5 & 76.02 \\
\hline 28 & 71.05 & 74.59 & 79.39 & 83.75 & 78.53 \\
\hline 29 & 69.35 & 72.62 & 76.92 & 81 & 76.22 \\
\hline 30 & 71.29 & 75.2 & 81.94 & 87.91 & 80.67 \\
\hline 31 & 73.55 & 79.22 & 84.87 & 89 & 83.43 \\
\hline 32 & 68.53 & 72.27 & 77.97 & 83.56 & 77.12 \\
\hline 33 & 76.76 & 81.2 & 85.1 & 88.93 & 84.52 \\
\hline 34 & 65.75 & 68.88 & 73.17 & 78.67 & 73.09 \\
\hline 35 & 68.37 & 72.17 & 78.46 & 85.34 & 77.83 \\
\hline 36 & 68 & 72 & 78.41 & 85.29 & 77.71 \\
\hline 37 & 68.93 & 72.63 & 78.24 & 85 & 77.95 \\
\hline 38 & 69.79 & 74.11 & 80.77 & 86.17 & 79.3 \\
\hline 39 & 76.19 & 81.29 & 86.48 & 90.14 & 85.1 \\
\hline 40 & 66.74 & 69.58 & 73.82 & 78.92 & 73.6 \\
\hline 41 & 68.19 & 71.23 & 75.68 & 80.5 & 75.22 \\
\hline 42 & 73.22 & 76.54 & 80.65 & 84.78 & 80.08 \\
\hline
\end{tabular}

Kode pewarnaan untuk menggambarkan keadaan kebisingan pada peta kontur yaitu warna hijau untuk tingkat kebisingan di bawah $70 \mathrm{dBA}$, warna kuning untuk tingkat kebisingan dengan tingkat kebisingan antara 70 - $80 \mathrm{dBA}$, dan warna merah untuk tingkat kebisingan di atas $80 \mathrm{dBA}$.

Kontur yang terbentuk pada peta kontur (Gambar 4) mengikuti nilai intensitas kebisingan yang sama nilainya. Kontur yang senilai akan menyambung dengan kontur yang memiliki intensitas kebisingan yang setara. Rapatnya kontur menunjukkan bahwa di sekitar titik pengukuran tersebut memiliki intensitas kebisingan yang beragam.

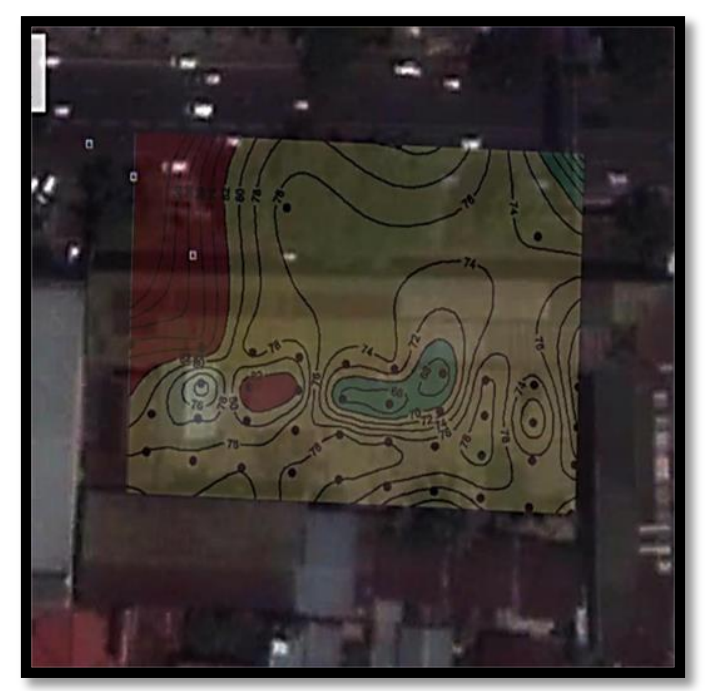

Koordinat titik survei dan nilai kebisingan yang diperoleh dibuatkan kontur menggunakan aplikasi surfer 7.0 untuk mengetahui sebaran tingkat kebisingan di kawasan SD.Bawakaraeng Makassar (Gambar 4). Selanjutnya, kontur tersebut diplot pada peta lokasi penelitian sehingga dapat dilihat peta sebaran tingkat kebisingan di SD.Bawakaraeng Makassar (Gambar 5).

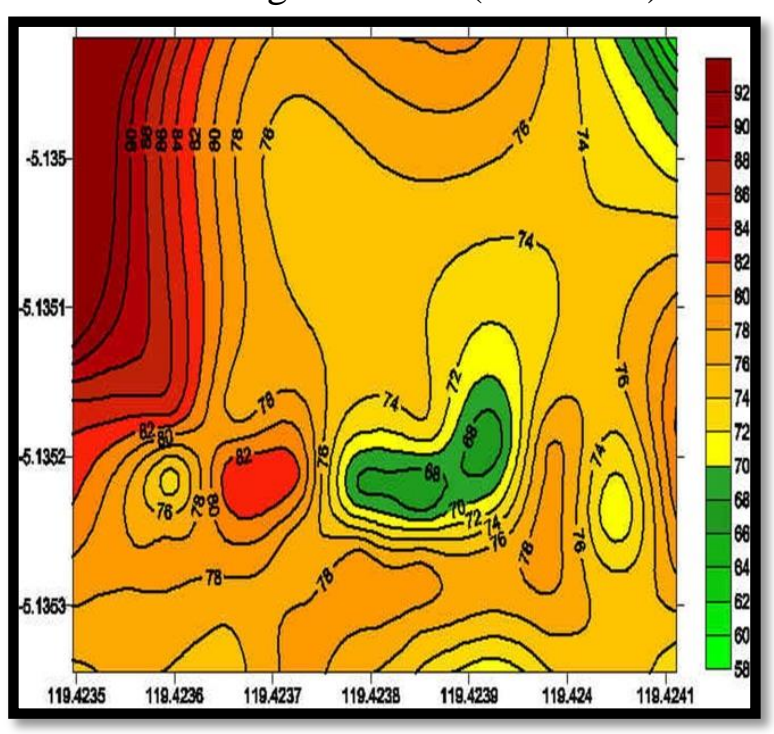

Gambar 4. Peta Kontur Tingkat Kebisingan di Kawasan SD Bawakaraeng

Gambar 5. Peta Sebaran Tingkat Kebisingan pada Kawasan SD Bawakaraeng Makassar

Berdasarkan peta kontur tingkat kebisingan (Gambar 4), tingkat kebisingan pada kawasan SD.Bawakaraeng Makassar dominan berwarna kuning, yang artinya tingkat kebisingan di kawasan sekolah dasar tersebut dominan berada di antara $70-80 \mathrm{dBA}$.

Untuk titik 1 sampai 39 terdapat di lapangan sekolah, 40 dan 41 berada di tempat parkir sekolah, serta titik 42 berada di dekat jalan. 
Tingkat kebisingan di atas $80 \mathrm{dBA}$ yang ditandai dengan warna merah terdapat pada titik 1, 26, 30, 31, 33, 39, dan 42. Titik-titik tersebut memiliki tingkat kebisingan yang tinggi karena untuk titik 42 berada di pinggir jalan, dan titik selain 42 berwarna merah karena berada di sekitaran kantin dan bagian bangunan sekolah yang dekat dengan traffic light, sehingga terjadi perlambatan kendaraan yang menyebabkan kebisingan. Akan tetapi untuk yang di lapangan, terdapat 5 titik pengukuran yang memiliki tingkat kebisingan yang tinggi, hal itu terjadi karena tingkat kebisingan pada titik tersebut diukur pada saat ada aktivitas di lapangan yaitu para siswa kelas 1 sedang pulang dan istirahat jam pertama sehingga banyak siswa yang berkeliaran. Kebisingan dengan tingkat kebisingan antara $70-80 \mathrm{dBA}$ ditandai dengan warna kuning terdapat pada titik 2 , $3,4,5,6,7,8,9,10,11,12,13,15,16,17$, $19,20,21,22,24,25,27,28,29,32,34$, $35,36,37,38,40$, dan 41, titik-titik yang berwarna kuning berada ditengah lapangan dan di tempat parkir sekolah. Tingkat kebisingan di area tempat parkir seharusnya lebih tinggi dibanding tingkat kebisingan di lapangan, tetapi yang diperoleh pada saat penelitian sebaliknya. Hal itu terjadi karena adanya kebisingan dari sumber lain yang menyebabkan tingkat kebisingan di lapangan lebih tinggi di banding tempat parkir. Kebisingan di bawah 70 dBA ditandai dengan warna hijau yang terdapat pada titik 16, 18, dan 23. Titik-titik yang berwarna hijau berada di tengah lapangan, dimana pada bagian ini di ambil pada saat siswa sedang belajar sehingga jarang siswa yang berkeliaran (Gambar 5).

Penelitian tingkat penerimaan kebisingan di sekitar SD Bawakaraeng Makassar dilakukan dengan membagikan kuesioner kepada responden sebanyak 250 kuesioner secara acak kepada siswa kelas $6 \mathrm{SD}$, guru, pegawai, dan orang tua/ pengantar penjemput siswa.

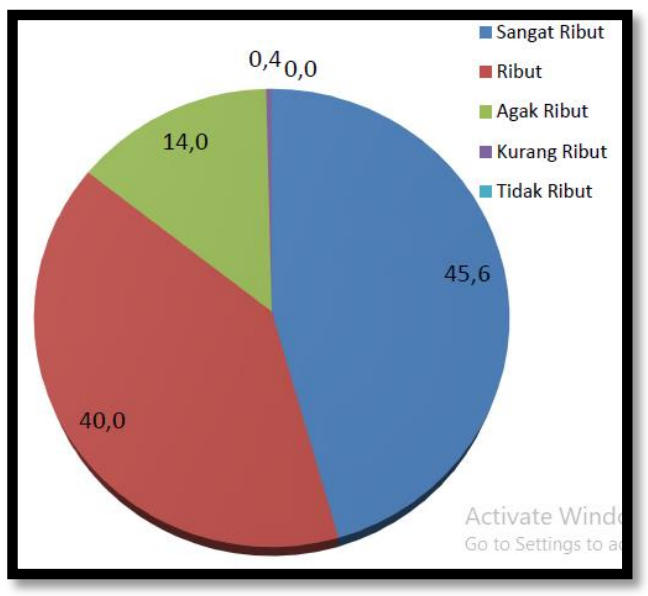

Gambar 6. Persepsi Tingkat Kebisingan di Kawasan SD Bawakaraeng

Dari hasil penyebaran kuesioner tersebut maka diperoleh persepsi masyarakat (siswa, guru, staf, orang tua/pengantar penjemput siswa) yang menyatakan bahwa mereka merasa sangat ribut dengan kebisingan yang terjadi pada kawasan SD.Bawakaraeng Makassar (gambar 6). Kebanyakan responden juga merasa terganggu dengan kebisingan yang terjadi pada kawasan SD.Bawakaraeng Makassar, terutama terhadap konsentrasi pada proses belajar mengajar (Gambar 7).

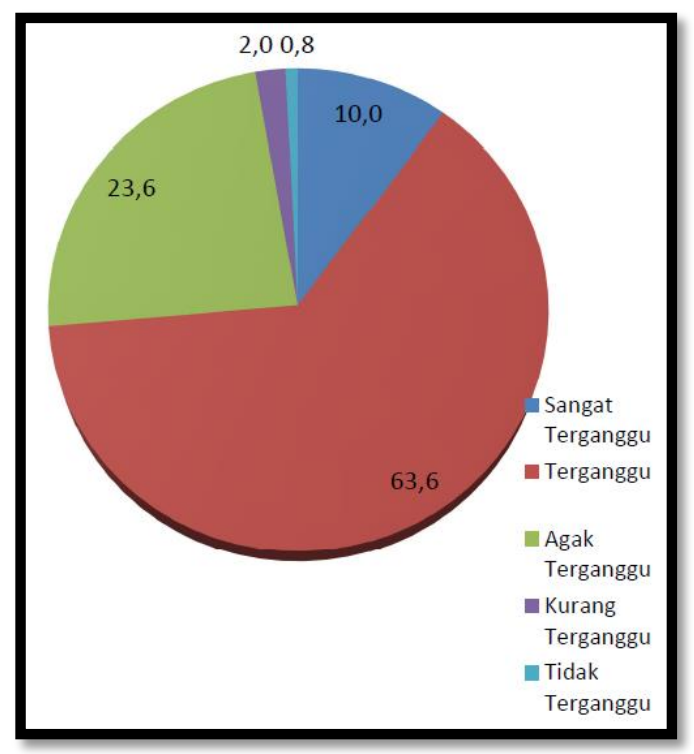

Gambar 7. Pengaruh kebisingan terhadap konsentrasi seseorang

Upaya pengendalian kebisingan ditawarkan dengan membangun noise barrier, 
penggantian/pembangunan perkerasan jalan berporos, pelarangan bunyi klakson kendaraan dan pembatasan kecepatan kendaraan (30-40 km/jam) pada kawasan SD Bawakaraeng (Gambar 8).

Dari empat (4) upaya pengendalian kebisingan yang diajukan ke responden, pembatasan kecepatan kendaraan (30-40 $\mathrm{km} / \mathrm{jam}$ ) yang paling banyak (130 orang) sangat setuju responden sebagai upaya pengendalian kebisingan yang sesuai pada kawasan SD.Bawakaraeng Makassar (Gambar 8).

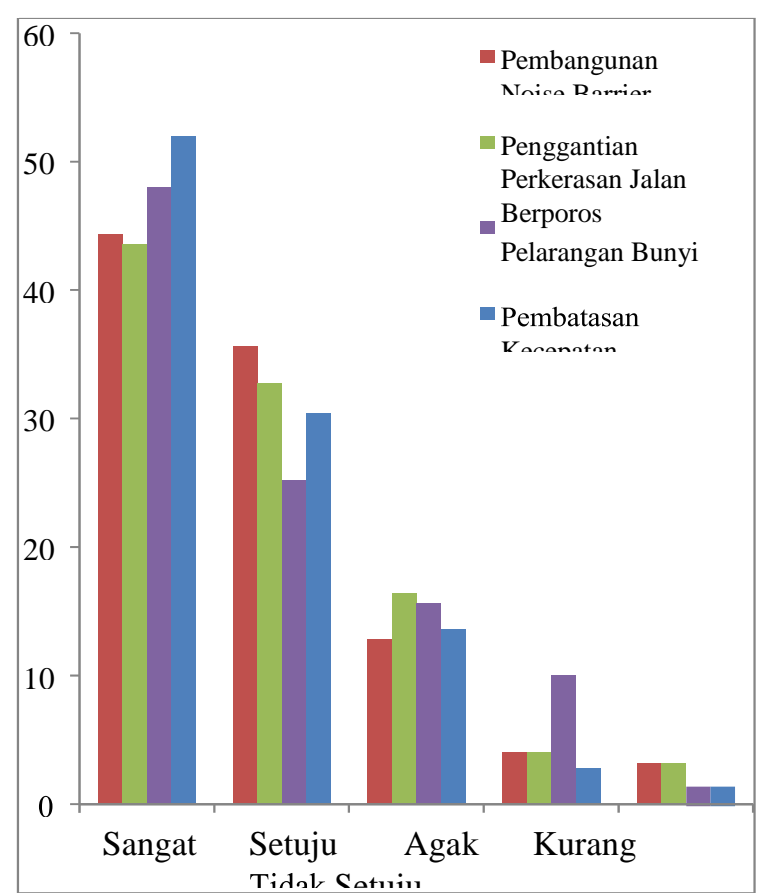

Gambar 8. Persepsi Upaya Pengendalian Kebisingan di Sekolah Dasar Bawakaraeng Makassar

\section{KESIMPULAN}

Setelah dilakukan pengukuran, perhitungan, dan analisa data tingkat kebisingan, maka dapat ditarik kesimpulan bahwa:

1. Nilai tingkat kebisingan yang diperoleh pada pengukuran tingkat kebisingan di kawasan SD Bawakaraeng Makassar melebihi baku mutu standar kebisingan pada kawasan sekolah menurut Keputusan
Menteri Lingkungan Hidup Nomor 48 tahun 1996, yaitu 55 dBA.

2. Berdasarkan pemetaan sebaran tingkat kebisingan di kawasan SD Bawakaraeng Makassar, warna yang dominan yang muncul adalah warna kuning yang berarti rata-rata tingkat kebisingan pada kawasan tersebut berada di antara $70-80 \mathrm{dBA}$, dan pada peta sebaran tingkat kebisingan warna dominan itu berada di lapangan sekolah SD.Bawakaraeng Makassar.

3. Dari 250 kuesioner yang telah dibagikan secara acak kepada siswa, guru, pegawai, dan orang tua/penjemput pengantar siswa untuk mengetahui persepsi masyarakat akibat tingkat kebisingan di SD Bawakaraeng Makassar, seluruh responden menyatakan bahwa mereka merasa sangat ribut dengan kebisingan di kawasan SD Bawakaraeng Makassar dan kebanyakan responden memilih pembatasan kecepatan kendaraan 30-40 km/jam sebagai upaya pengendalian kebisingan yang dianggap sesuai pada kawasan SD Bawakaraeng Makassar

\section{DAFTAR PUSTAKA}

Anonim. (2012). Perkembangan Jumlah Kendaraan Bermotor di Makassar Tahun 2012. Dinas Perhubungan Kota Makassar, Sulawesi Selatan.

Anonim. (2013). Pertumbuhan Kendaraan di Makassar Tahun 2012, Satlantas Polrestabes Makassar, Sulawesi Selatan.

Hustim, M. dan Kazutoshi, F. (2012). Acoustical Characteristics of Horn Sound of Vehicles. Japan: Kyushu University.

Keputusan Menteri Lingkungan Hidup No. 48. (1996). Baku Tingkat Kebisingan, Menteri Lingkungan Hidup, Indonesia. 